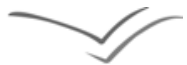 \\ VERSITA
}

DOI 10.2478/jped-2013-0008

JoP 4 (2): $139-161$

\section{The production of present and absent presences in education ${ }^{1}$}

\section{Anneli Frelin, Jan Grannäs}

Abstract: Drawing on the distinction between absent and present presences, this article contributes to our understanding of how new managerial and performative discourses are played out in a secondary school context in Sweden. The consequences of numerous educational reforms during the last 20 years include a surge of new independent schools and increased segregation between students due to individual school choice. Following international trends, a yearly national municipal school ranking is published, drawing much attention both in the media and on the policy level, intensifying pressure for results at the municipal level. A case study was conducted in one bottom-ranked Swedish secondary school over the 2012-13 school year, focusing on how relationships between students and staff were negotiated in informal spaces and places. The results illustrate how absent presences and present presences are produced in the practice of schooling. The present presences were publication of results, raising merit scores and grading pressure, and the absent presences were the role of the media in the self-image of schools, increased workload for teachers, the misuse of statistical data and demoralization and determination. The results contribute to the understanding of a) the challenges that teachers and schools are faced with as a consequence of the new managerial and performative discourses in educational settings, and $b$ ) the means they draw on to face and resist them in their everyday practices.

Key words: absent presence, managerialism, performative, policy enactment, present presence

This work was supported by AFA Insurance, Sweden [grant number: Dnr 110145] as part of the research project Spaces in-between. Sustainable relationships as prevention against threats and violence. We would like to thank the anonymous reviewer for valuable comments and our language editor for careful editing. 
Everyone is racing to the top! Nations, schools, politicians, policymakers, school leaders, teachers, parents and students are all participants in this race. Why are they doing this? The biggest threat, in these times of globalization, seems to be an economic one. Also, in order to combat the threat, and thereby win the race, it is suggested that the key is the best and most efficient educational system. But how do we know who the winner is? The answer to that question is by making comparisons. International comparisons are used as arguments for a surge of educational reforms across the world. On the one hand, the necessity for comparisons spurs demands to conform and measure practices and outcomes, and, on the other, requires transparency and accountability from those who work and study in schools. The demands for comparisons, articulated in part through the discourse of managerialism and performance, also require the reduction or reorganization of the complexities of everyday school life in order to produce measurable outcomes. These changes have pervasive consequences for education and for educational relationships.

The purpose of this article is to contribute to the understanding of how new managerial and performative discourses are played out in a secondary school context. A case study was conducted in a secondary school over the 2012-13 school year, focusing on how relationships between students and staff were negotiated in informal spaces and places within a school setting but are not directly linked to the formal mission of the school. It illustrates how absent presences and present presences are produced in the practice of schooling and helps us to understand a) the challenges that teachers and schools are faced with as a consequence of the new managerial and performative discourses in educational settings, and b) the means they draw on to face and resist them in their everyday practices.

\section{From the Global to the National}

Neoliberal ideology has been very pervasive over the last 30 years. This has led to a massive reframing in society, and given greater importance to the new managerial discourse. Along with these neoliberal tendencies, neo-conservative ones are also in play, thus creating an odd combination of marketization and centralization of control (Apple, 2004, 2009; Kaščák \& Pupala, 2011; Laitsch, 2013). Apple describes this as: "educational reforms that have centered around neoliberal commitments to the market and a supposedly weak state, neoconservative emphases on stronger control over curricula and values, and 'new managerial' proposals to install rigorous forms of accountability in schooling at all levels"(Apple, 2010, p. 175).

The global language used to describe education has increasingly borrowed its rhetoric from the business world, for example the concepts of accountabi- 
lity, efficiency and performance standards, as part of the economization of education (Hopmann, 2008; Lipman, 2009; Takayama, 2013; Taubman, 2009).

The policy technologies upheld in order to conjure constant improvement in measurable performance are management, market and performativity, all of which are encoded in government legislation and policy documents (Ball, Maguire, \& Braun, 2012). However, these do not take into account the dynamic, complex and political nature of the educational context. Today's zeitgeist administrative displacements, such as new ideological, political or administrative ways of governing the educational system, have consequences for the educational system and for teachers' work, and constitute challenges for professionals in educational arenas - at national and local levels, such as in school (Ball, 2004; Ball et al., 2012; Fransson \& Grannäs, 2013; Furlong, Cochran-Smith, \& Brennan, 2008). The dominant trend is for educational systems to be increasingly governed by "managerialism" - implying a kind of one-size-fits-all, efficiency-oriented set of methods (Locke, 2009).

Gewirtz and Ball (2000) describe two discourses of school headship as "new managerialism" and "welfarism". The latter is connected to values such as social justice and compensatory practices, while the former connects to more instrumental values and a market logic. The aspiration to produce more efficient educational systems through a surge of reforms is accompanied by this managerial form of government, which serves a particular vision of education for global competition that is not always compatible with the public purposes of education, such as fostering democratic citizenship. This shift can be described as moving from an educational system serving the public good to one serving the private good (cf. Englund, 1994). Please see the section below entitled From the national to the local - the Swedish school system for further elaboration.

Drawing on Apple (2010), it can be argued that the neo-liberal and neoconservative tendencies in society - operationalized by "the new managerial" and a rapidly emerging bureaucratic, technocratic managerial group - have contributed to a shift in the perception of democracy. This shift contains discourses that have opened a space within the state for that kind of expertise, including a constant need for audits, "evidence", rationalization and standardization. A shift has taken place from a collectively driven "thick" democracy with an emphasis on the public sphere and common interests, to a more highly individualized and consumer-driven "thin" democracy (cf. Barber, 2003; Ranson, 2003). Based on the assumption that the educational arena is a market like any other, and can be organized by market logic, a commodification of all levels in the educational system occurs (cf. Ball, 2004). In Ley's words: "The facts suggest that market- 
driven politics can lead to a remarkably rapid erosion of democraticallydetermined collective values and institutions" (Leys, 2003, p. 4). This development means that the private sphere, which is based on competitive individualism, economic rationalities and economic relationships, grows at the expense of the public sphere. In turn, a society and culture prevail that do not rest on trust, solidarity and shared values to the same extent (Ball \& Olmedo, 2013).

Although countries differ in their responses to these developments, in many places the educational system has responded with an increased focus on national tests and other control features, where international comparisons like PISA are given significant attention (Bieber \& Martens, 2011; Hopmann, 2008; Taubman, 2009). Hopmann argues that a one-sided "NCLBinduced"2 focus allows for

the transformation of the apparent problems with equity and equality, minorities, special needs, gender, etc., into individualized liabilities whose impact on achievement has to be minimized, if not eradicated. (p. 441)

The performative function of market-oriented language makes it hard for teachers to speak out and 'make sense' using concepts outside the managerial discourse (see, for example, Hoyle \& Wallace, 2007; Mulcahy, 2010). It has also contributed to aligning education to the economy, in preference to other more social/democratic/ethical/and so forth purposes.

One consequence of managerialism (including the language used, the incentives given and the allocation of economic resources) is that certain features will stand out, or "count" (see e.g. Apple, 2009; Kumashiro, 2008). Things that count include lessons, homework, testing, performance, policy documents, national tests and so forth. However, another consequence is that other things do not count, but become obscured.

The core of accountability is narrowly focused on student achievement measured by "academic standards". Other functions of schooling (such as the role school plays in local communities or in shaping society) are hardly mentioned. At the same time academic achievement is reduced to that which can be reported as "statistically valid and reliable", leaving out any educational or social achievements which cannot be counted as required (Hopmann, 2008, pp. 429-430).

\footnotetext{
2 No Child Left Behind, NCLB, pertains to the Act passed in the US in 2002 that focused on testing and accountability, but at the same time opened up for marketization and privatization in education (Apple, 2007).
} 
These are things that are impossible to address within the managerial discourse, but that can nevertheless influence educational practices in profound ways. In this paper we aim to use concepts that highlight some of these consequences. The phenomena that are not included in the new managerial discourse and are pushed away are called absent presences (see also Apple, 1999). Consequently, the events that can and are allowed to occur become present presences (Frelin \& Grannäs, 2011).

As Ball et al. hold, policy is enacted rather than implemented. Policies are set within existing values, commitments and forms of experience; a process that is far from straightforward and rational and produces a number of social relations, positions, practices and performances, for example when schools are labelled as 'outstanding', 'coasting' or 'failing' in relation to the discourse of standards which represents a particular, and on the whole indisputable, vision of what schooling ought to be like (Ball et al., 2012). Thus, for schools it becomes imperative to solve the "policy problem of becoming a 'good' school" (p. 130), which in turn leads to efforts to evoke the 'good' teacher and 'good' student in a process of normalization. The opposite is also produced, however. Yates (2013) asks:

what will prevent some students suffering the reputational and other consequences of being in schools measured as doing worse, when the benchmarking relativities built in to the approach (the 'race' to the top) entail that some schools have to be classified as doing worse? (p. 46)

The efforts and resources required to boost performance give varying results in schools. Some teachers are very diligent but only achieve modest results, mainly because socio-economic factors constitute an "active force" and not just a backdrop (Ball et al., 2012). Efforts to manage reputation, student intake and staff recruitment become increasingly important as political and emotional responses to external pressures become part of this context and as schools are characterized by precariousness. Furthermore, Ball et al. argue that the role of the material context, such as space and the condition of buildings, is an active factor in policy enactments (cf. Frelin \& Grannäs, forthcoming).

Even though there are ongoing negotiations, translations and transformations within policy enactment, the policy pressure is not equally distributed. The schools, or in some cases subject departments, that perform well in tests and inspections have considerably more autonomy in relation to policy initiatives, so-called "earned autonomy". In other cases, and increasingly, policy is being enforced through practices such as lesson observations and other forms of surveillance (Ball et al., 2012; Lipman, 2010). 


\section{Consequences for Teachers}

Teachers and other professionals who work with people are responsible for other people and expected to fulfil their professional duties according to laws, policy documents, guidelines and other types of directives. In many countries teachers perceive decreased respect for teachers, which relates to the neo-conservative discourse and an emerging consumer attitude to education, where teachers are blamed for student failure (Müller et al., 2011). However, policy enactments serving the managerial discourse can also be challenged by counter-discourses, some residing in the common histories of the staff, which serve to criticize the new policy (Ball et al., 2012; Ball \& Olmedo, 2013). These require spaces for enunciation, though, and the consequences of, for example, work overload make time for reflection and critique scarce: "there is a lack of space for 'other' discourses, the historic archive of 'democratic' or 'inclusive' teaching is always in danger of erasure" (Ball et al., 2012, p. 68). Resistance at the discursive level also means questioning oneself and "the obviousness of things" (Ball \& Olmedo, 2013, p. 90).

Spaces for negotiation and contestation of policy are for the most part occupied by responsibility and necessity as teachers strive to do the best they can in an environment of increasingly competitive performativity. Ball et al. argue that the immanent tensions between the interests of students and the interests of the school sometimes make teachers uncomfortable "as they measure and compare their students and seek to extract 'productivity' gains from them" (p. 73), and that the role of psychosocial and affective dynamics have not been given sufficient attention (cf. Hargreaves, 2000; Zembylas, 2003). Testing and competition tend not only to produce incentives and individualism, but also stress, frustration, discouragement, depression and demoralization for teachers as well as students (Ball \& Olmedo, 2013; Yates, 2013). The focus of teachers' work is steered towards improving performance, or rather, some performances.

According to Ball et al. (2012), the increased use of artefacts, such as software systems for data production and analysis, is also a key element in enactments of policy which takes up teachers' time, attention and effort. They argue that since teachers are "working their socks off" (p. 95), they direct their energies towards coping and keeping up, which decreases the possibilities for systematically reflecting on the contradictions embedded in their tasks, or on the wider consequences for their students. The teacher subjectivity that is produced through policy is colonized by institutional priorities even in the most immediate interactions with students, "defined more by responsiveness than principle, pragmatism rather than reflection, action rather than judgment" (p. 96). In our case study schools, this subjectivity 
was ubiquitous and any critical thinking or resistance in the light of other and prior discourses was rare and fleeting.

Another consequence is that the increased time spent monitoring and recording students' work limits the opportunities to interact with students and colleagues. Gewirtz (1997) termed this a "decline in the sociability of teaching" (p 230). Close relationships with students tends to be a central aspect for teachers across nations, particularly for students who are not doing well academically (Davidson, 1999; Frelin, 2013; Grannäs, 2011; Oreshkina \& Greenberg, 2011). As building and sustaining relationships with students takes an investment of time (cf. Oreshkina \& Greenberg, 2011), the colonization of time may cause more harm to those who need it most. Moreover, as the relational basis of a school organization promotes the achievement of academic results, severing this in the name of narrow performative academic purposes can be counterproductive (cf. Bingham \& Sidorkin, 2004; Lingard, Hayes \& Mills, 2003).

\section{From the National to the Local - the Swedish School System}

Even Sweden, which has a highly developed welfare state, has increasingly been drawn into neoliberal-oriented trends in recent decades. Broadly, the Swedish development can be described as consisting of two major trends. One trend involves radical organizational reforms at various levels of Swedish society aimed at efficient education, inspired by New Public Management (see e.g. Blomqvist \& Rothstein, 2008; Bottery \& Barnett, 1996), decentralization and, vital to the school system, the establishment of independent schools. The other trend involves the introduction of a new system with a focus on accountability and an emphasis on evaluating student achievement (Bunar, 2008; Englund, 1994, 2010). According to Beach and Sernhede (2011):

This tendency is also clearly recognizable in the educational systems in these countries, such as in Sweden, where educational consumerism and individualism have replaced comprehensiveness and inclusion as capstones of recent developments. A number of elements have been involved. They include the introduction of open enrolment, per capita funding and deregulated admission procedures that encourage schools to compete for student enrolments and parents and students to act as consumers of education with the possibilities of free choice. (p. 258)

Recent studies on the effects of this "freedom of choice reform" show that middle-class Swedish families benefit most from the reforms. Other 
community groups, such as the working class and immigrant groups, have not benefited to the same extent. In Sweden, it is now clear that the neoliberal-inspired reforms introduced in the last 20 years have contributed to the rapidly increasing segregation of society as a whole, and the school system in particular (Beach \& Sernhede, 2011; Bunar, 2008; Skolverket, 2012). Or, as Beach and Sernhede put it: "Students with predicted higher test scores are now more valuable to schools while pupils with predicted lower test scores and with more complex learning needs, such as working-class and ethnically different pupils, have become less useful to the school's place in the market" (Beach \& Sernhede, 2011, p. 259; cf. Minarechová, 2012).

Ball et al. (2012) depict a delivery chain from the global to the individual, where pressures to perform are passed down through the system. When adapted to the Swedish system, the delivery chain looks like this:

\section{Global}

National

Local

School

Classroom

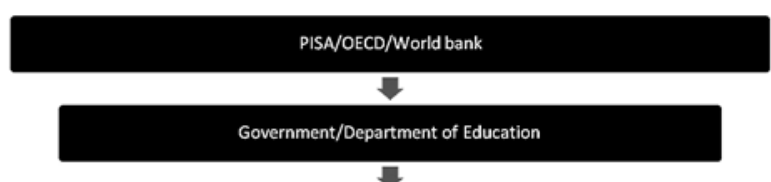

National Agency of Education

$\checkmark$

Local authorities

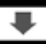

Schools and competition

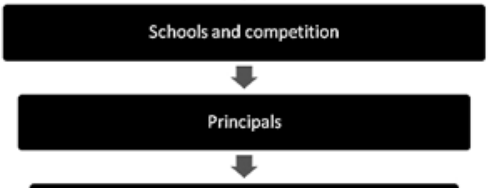

Team leaders/ Head of subject

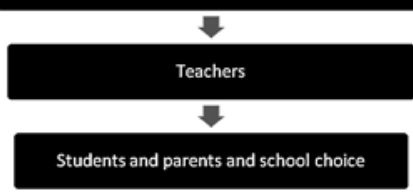

Figure 1: The delivery chain.

Source: adapted from Ball et. al, 2012

Different levels have been added by us for the purpose of clarity. Twentyfive years ago almost all Swedish teachers were employed by the state, but the schools they worked in were run by the municipalities. Two reforms changed this situation. First, the municipalities assumed responsibility for 
teachers' employment, and second, a school choice reform paved the way for privately run but publicly financed schools, thereby forming a 'quasi-market' (cf. Wilkins, 2012). The latter has resulted in an explosion of so-called independent schools over the last two decades, and now as many as $40 \%$ of upper secondary schools are independent. Recent studies have raised concerns about the increased segregation and inequality of results among students.

A study undertaken by Bejerot covering over 3,000 teachers and headteachers indicates that over the last 20 years there has been a radical increase in teachers' workload and a marked decrease in influence and support. For example, $60 \%$ of teachers report that they often work during their lunch breaks, of an evening and at weekends (Bejerot, 2013). There are also strong indications of increasing grade inflation. The National Agency of Education states that: "Grades express the extent to which the individual pupil has attained the national knowledge requirements laid down for different subjects" (Skolverket, 2011, p. 19). Students who do not achieve pass grades in at least eight subjects are not eligible for national upper secondary school programmes. This policy exerts a strong influence on secondary school teachers' work, which is directed towards helping students to pass (Wedin, 2007). The National Agency of Education (2012, p. 387) draws the conclusion that "the increased competition between schools, in combination with pressure from students and parents, and expectations from local management creates stronger incitements for grade inflation" (p. 2).

\section{Method}

This paper presents results from a research project that set out to explore the relational interplay between school personnel and students and its functions and complexity in the secondary school context. The study is explorative and generative. Studying a complex phenomenon requires an open approach that allows for a number of different variables. The choice of method, in this case a case study, is designed to acquire a deeper understanding of the complex relational processes that develop over time (Creswell, 2009; Yin, 2003).

In Sweden, students aged 13-15 years attend compulsory secondary school, after which most apply to a non-compulsory upper secondary school programme, some of which are college preparatory and some vocational. Secondary schools are thus the last stage at which students are placed in heterogeneous groups. The primary focus of the study is relationships between students and staff and the ways in which these are negotiated in informal spaces and places within a school setting but are not directly linked to the formal mission of the school. 
A year-long case study was conducted during the 2012-13 school year at a secondary school that had recently been renovated and was working to improve its environment. Multiple data sources were used, including document analysis, mapping, contextual observations and interviews. Official statistics, newspaper articles and school quality reports were used to contextualize the case (Creswell, 2009).

The quantitative data was retrieved from the databases of the National Agency of Education with a view to contributing to a deeper contextualization of the case school and triangulating the data. The analysis of documents, interviews and newspaper articles is based on a thematic analysis (Boyatzis, 1998; Braun \& Clarke, 2006). The actual work of processing, analyzing and interpreting the material was conducted using Atlas.ti software through coding, linkages and memos. The thematic analysis involved close readings, back and forth, of transcripts and documents. Furthermore, in the analysis we looked for similarities and differences, with a particular focus on how teachers deal with the consequences of policy and new managerial languages and practices. During the analysis process notes were made in support of the ongoing analysis, together with reflections on the theoretical framework. The thematic analysis was continuously performed at two levels: one to analyze that which is directly visible (explicit), and the second to analyze the underlying latent meanings (implicit) (Boyatzis, 1998; Braun \& Clarke, 2006). The purpose of the case study presented in this article is to contribute to the understanding of how absent presences and present presences are produced in the secondary school context.

\section{The Production of Present and Absent Presences}

The case study school, Tallvik, is a secondary school located in the small industrial town of Bruksta, in Sweden, and is one of two secondary schools in the municipality. The other is an independent school. Students attend Years 6-9 (12-15 yrs of age) and each year level has two or three classes consisting of about 20-30 students, with a total of around 200 students. The school was built in the 1960s. In 2009 major renovations were carried out, which were much needed as the school had not been very well maintained. The current principal was formerly a student at the school and is therefore well connected to the local community. The staff members are experienced and the numbers have remained more or less stable over time. The school has several long-standing traditions, including putting on shows at Christmas, and having a well-respected and influential Student Council. Around ten years ago, an independent school was established in the municipality, which attracted large numbers of high SES (Socio-Economical Status) stu- 
dents, for the most part in line with national trends (Skolverket, 2012). This was one of the reasons for the drop in the number of students at Tallvik, which originally had twice as many students as it does today.

In order to address the consequences of the managerial discourse, the presentation of the results is divided into events that are made visible or invisible in this discourse, that is, present presences or absent presences (see above).

\section{Publication of Results (Present Presence)}

The national ranking of education in municipalities ${ }^{3}$ is largely based on students' results, but also on factors such as teacher competence and salaries. Ranking receives great media attention, and in 2012 Bruksta was among the municipalities to come at the very bottom of the list. One factor that contributed to the ranking and received the most attention at municipal level was the students' low merit scores (based on their grade point averages).

\section{The Role of the Media in the Self-Image (Absent Presence)}

The interviews with the staff and the students indicate the importance of societal expectations and influences. The image of the school in newspaper articles impacts the surrounding society's expectations of the students and school staff, because the way the teachers at Tallvik describe themselves and their school aligns with the media image. At all levels of the local education system, i.e., from the Chief Education Office to the students at the school, there is awareness of a variety of problems; an image that is mirrored in the media. While the official categorization of schools as outstanding or failing is important within the managerial discourse (present presence), the response among the teachers and students to this image constitutes an absent presence, as it is not part of this discourse. A social studies teacher and head of subject, Lisa, says this about the media image of Tallvik:

$\mathrm{Mmm}$, we experienced that as something negative. It seemed harsh, we were hard pressed ... but that was some time ago. The journalists had produced figures from 2008 or 2009, or something like that, first nationally and then locally. We had poor scores then, and the journalist came down here ... to the cor-

3 http://www.lararforbundet.se/web/ws.nsf/webbIndexsida?ReadForm\&index $=04978$ 08B2ABF6128C12572C80033F58F 
ridor and made the mistake of interviewing the students in my class without permission from the school or parents. She asked them why the results were so bad, and referred to something that had happened three years ago. She talked to the students and almost assumed that the present-day students also had bad grades, because she then went on to ask: Why is it that your results are so bad?

When I added up the results from all the schools in the area, they had the same scores. But that wasn't news. No, the media just focused on one school and said it was below par. You can see why we don't have a positive image of the mass media.

According to several teachers, the bad press, which is a recurring topic of discussion, serves to drain them of energy, and in addition reinforces students' negative images of themselves and their school. There are additional reasons for the perceived unfairness of the media coverage, as is indicated below.

\section{Raising Merit Scores (Present Presence)}

The pressure for improved results is implicitly present in for example meetings between municipal officials and teachers' union representatives. The renovations at the school facilities were costly, and due to expansion of the independent school there were fewer students at Tallvik than had been anticipated when the renovations were carried out. The school's high maintenance costs were pointed out at meetings, and Lisa sensed that because the municipality had invested so much they also expected the merit scores to rise, despite the fact that the higher costs were largely out of the teachers' control.

The municipality's Chief Education Officer was the principal at Tallvik three years ago (2010). At the time she presented the then recently published low merit scores to the teachers in the following way:

We took a real dive ... I just had to bang my fist on the table: This is not good enough. So everyone realized that there was only one way forward, and that was to shape up. Everybody was aware of it. It was so obvious: This just doesn't fly, this is not good enough. It was such a clear message. 
The pressure to raise the merit scores resulted in several practices, including revision classes during the holidays and help with homework after school (cf. Ball et al., 2012; Minarechová, 2012). The former principal started to audit teachers' lessons on a regular basis; a practice she lamented that her successor had not kept up. A key reason the current principal had not pursued this path was because she spent a substantial part of her time on issues pertaining to health, social conditions and student welfare.

Another practice that the former principal launched was the implementation of charts to identify and visualize "target students", i.e. those who were in the 'risk zone' of failing in one or more subjects. Teachers were instructed to put an X (a fail-warning) for their subject on the class lists in the staff room and to repeat this each month. This practice required teachers to analyze their documentation and to make continuous judgements as to whether to give fail-warnings to their students or not. As the science teacher, Göran, suggested, he would rather give too many warnings than too few, because he did not want to risk missing students who might fail.

\section{Increased Workload for Teachers (Absent Presence)}

The monthly practice of documenting fail warnings was additional to the other work tasks and was later extended. The teachers were also asked to write monthly performance statements for each target student, which took them several hours each time. As teachers' workload is already extremely high due to the increased demands for documentation, which can be regarded as present presences (see the national studies referenced above), they had little choice but to cut down on other tasks, often against their professional judgement. For example, Göran argued that the increased documentation affected his lesson planning negatively, which meant that his lessons were not as well planned and interesting as before. This naturally disadvantaged his students' learning.

\section{Grading Pressure (Present Presence)}

Bruksta, the town in which Tallvik is located, is unique in terms of the proportion of attendance at independent schools, which is one of the highest in the country. One consequence of the increasing influence of managerialism, and the subsequent demand for performance, is that the data is increasingly quantitative. This data formed the basis for many discussions in the municipality about the reasons for the poor merit scores, for which the teachers were held accountable. Lisa and the current principal argued that one reason for the low merit scores was due to teachers being 
careful to avoid grade inflation and making concerted efforts to give accurate grades, which was in part supported by an investigation into the schools in the region by a local newspaper. ${ }^{4}$ The data indicated that students in the region who progressed from secondary school to upper secondary school often had a significant drop in their grades. This was particularly true for some schools, whereas students from Tallvik were able to maintain their grades. Lisa said that: "the situation is remarkable, if I pass my students, no one questions my grading. But if I fail them, then I am questioned." This argument was mentioned by several of the teachers.

\section{Problems With Statistical Data (Absent Presence)}

Statistical evidence can easily be interpreted in misleading ways, because the samples in small municipalities are limited.The scores ofonly a few students can dramatically lower or raise the municipality's merit score averages. Lisa, the social science teacher, remarked:

Competition means the results hit us hard ... One or two students in the statistics for us is... it is so awful I tell you, because we have got a few new students in the ninth grade who have not attended school regularly in years, and have big problems. That is two out of our fifty, and already we know: Ouch, we're going to be in the newspaper again, because our scores went down again.

With only around 50 students per grade level, the results can vary dramatically from year to year, as the table below illustrates. Tables 1, 2 and 3 show the percentage of students attaining the goals in all subjects (Table 1 , the total number, Table 2, girls, Table 3, boys). The bottom graph illustrates the results at Tallvik during the years 2008-2012, while the one above shows the results of the municipality in total. The black horizontal graph shows the national average.

4 The name of the newspaper has been omitted for reasons of confidentiality, in line with national ethical guidelines. 
Table 1, 2, 3

Percentage (\%) of students who passed in all subjects

In total

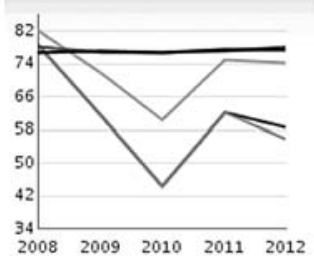

Girls

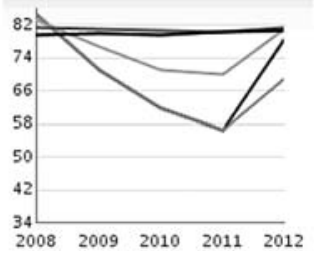

Boys

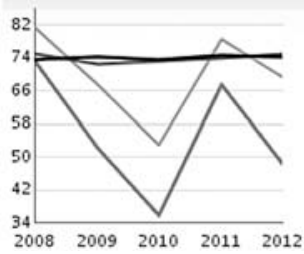

School

Municipality, Tallvik

Municipality, Tallvik and Independent school

Category of Municipalities (similar)

Nation

Figure 2: Variations in results at school and municipal levels

Source: SIRIS, the Swedish National Agency for Education's online information system. [http://siris.skolverket.se/siris/f?p=SIRIS:33:0]

The dramatic variance between the years, which is absent at the national level, illustrates the problem of assigning any great importance to this annual statistic at the municipal level.

\section{Demoralization and Determination (Absent Presence)}

In parallel to the study conducted by Ball et al (2012), the neglect of socioemotional factors, such as frustration, discouragement and demoralization in policy enactment, is evident in our results, as the pressure created on the way from the top to the bottom of the delivery chain hits staff and students. Peter, a teacher, argued:

We hear all the time that we have to improve, and that can get dangerous, I have brought this up. Because at some point you have to get the sense that the work you do is good, even if the results are bad. People work and work, we really do most of us, and then you get: Yes, but you have to improve.

Interviewer: Who says so?

Peter: Those from above

Interviewer: From above where?

Peter: Well, politicians. 
The pressure from local politicians and management is to some extent perceived as unfair. Lisa asked herself whether she had become so much worse in her 30 years of teaching, or whether there were other parameters in the equation. She reached the conclusion that there had to be. Peter said that teachers at the school were very competent and experienced, but that:

Somewhere you have to look at other factors, and not just the teachers, throw dirt at us. Because we are battered, as soon as, every year when there are bad results, then we at Tallvik carry the blame. The students come from other schools too, but it is here when they get grades that we take the hit, of course you get beat up in the end. Despite the fact that you work yourself to death, because I argue that most of us do. ... In fifth grade 50\% passed and in ninth grade almost $80 \%$ passed, you have to look at it that way too. We raised the results by almost $30 \%$ but you don't get anything for that, they just look at the end results and by God that is so bad. Of course you get beat up, you want to do a good job. You want to feel: Damn it Peter, you did good there!

The principal said that she had tried to counteract this pressure on teachers from the municipal level by repeatedly pointing to positive trends in the school and by praising her teachers. This was also because she experienced how some, particularly ambitious and excellent teachers, tried to avoid criticism and started to look for jobs at other schools where they could more easily attain the visible reinforcement of doing a good job in the form of good student grades.

However, a different but equally unintended consequence of the pressure to produce results is an increased loyalty and determination among the staff. The common "we" emerges very strongly in relation to the perceived unfair competition from the independent school and the intensified pressure for results from above.

\section{From Absent to Present - Evoking Educational Relations into Presence}

The staff grapple with the new managerial discourse as they enact policy, which often involves creatively dealing with irreconcilable discourses. At Tallvik, the new managerial discourse rubs up against the longstanding welfarist tradition of Swedish education, which emphasizes fostering democratic citizenship and a communal spirit; a discourse that is very much alive among the staff. The welfarist/democratic discourse emerges in the inter- 
views, but also in the relations fostered in the common areas of the school, where staff make a habit of greeting students and chatting informally with them. Developing personalized relationships is something that teachers perceive as one of their tasks. Sven, for example, argued that the relationships that he built outside the classroom helped him do his job:

The kids, they are central to the school. In terms of time, the time I give them in the corridor and what they give me in return, it all comes back to me during lessons. If we share a relationship, we talk and I listen ... then they'd rather not make trouble during classes either. So we save time. It's the same in the school cafeteria, it's fun to sit with the kids there, although there are some who ... we often sit together with. Who think, well, they have found someone who can listen.

This is also apparent in several of the services the school provides, such as the student welfare team and the student welfare duties that are part of staff job descriptions, such as the school host and the cafe host. ${ }^{5}$ However, these positions tend to come under threat in times of austerity, despite the value that the staff and students assign to them.

The pressure to raise merit scores that resulted in the identification of target students and failing warnings also produced an interesting initiative when the current principal asked for suggestions as to how to help these target students. One suggestion was to pair each student with a "coach", someone other than the grading teacher and who had a positive relationship to the student in question. The task of the coach was to connect personally with the student and support her or him in aiming to achieve a pass grade. This practice constitutes a conflation of new managerial and welfarist/democratic discourses, in several intriguing ways.

First, the main basis of the coach-relationship is the perceived quality of the teacher-student relationship, rather than subject-matter knowledge, which involves evoking relational qualities that are either perceived as taken for granted or as unimportant within new managerial practices and language (cf. Frelin, 2013). Second, the teachers volunteered to coach these students without further remuneration, which added to their already intense workload. Third, the teachers used tools from their welfarist/democratic discourse toolbox. The ultimate purpose of these coach-relationships

\footnotetext{
5 The school host has a special responsibility for students' interaction in the common areas, and runs a café in the main hall together with the café host. They are also available for the students and offer help with practical matters.
} 
was to meet the demands of the new managerial discourse. And fourth, concurrently, these relationships, which benefited the students, could constitute means for other public/democratic ends.

The fact that the public/democratic discourse is evoked can be viewed as a movement from the bottom up to enact policy in a way that either conforms with, counteracts, transforms or negotiates the delivery chain of the managerial discourse. It also makes absent presences present, at least at school level, which entails negotiating personal costs and professional values, responsibility and/or well-being. Furthermore, it can be viewed as creating and/or preserving educational spaces for the public good.

\section{Discussion}

The results show how the policy pressure created in the delivery chain plays out at local levels, from municipal directives to teacher-student relationships and the experiences of the teacher (cf. Ball et al., 2012). The new managerial discourse steers the focus of the schooling towards "knowledge" result measures, which are present presences within the discourse. In a rapidly growing audit culture, comparisons in the form of league tables and merit scores published by the media are means through which the presence is established. The carriers of this discourse hold teachers and students individually accountable for factors that are not entirely within their control, such as marginalization and segregation due to the school choice reform, which have become absent presences within this discourse (cf. Beach \& Sernhede, 2011). These factors are instead structurally influenced; this is something that has been neglected. However, lately a number of reports pointing to the relation between poor results and increased segregation have had an impact in the media and on the public debate, which can be viewed as a move initialising the shift from absent to present presence.

The teachers at Tallvik, who are subjected to such blaming and shaming, describe their feelings of demoralization. The mechanical delivery chain and the blame game may also exacerbate segregation and inequality as competent teachers move to other schools in order to preserve their professional self-image. In the cognitive framework of measurement, such feelings are largely treated as absent presences because they are not given any value or significance.

However, several practices of resistance towards the municipal management are set in play by both the teachers and the principal. Evoking the welfarist/democratic counter-discourse, residing in the common history of the school and the town, the principal highlights values that are absent presences within the new managerial discourse, such as the work of the Student 
Council and the experience and hard work of the teachers (cf. Apple, 2010). Several teachers in the study talked about the unfairness that the scores represented, thus questioning the "obviousness" of the new managerial and performative discourse (cf. Ball et al., 2012).

The results also show how policy enactment takes place through teachers' grappling with the consequences of the new managerial discourse and how these impose on the welfarist/democratic discourses. Even though the directives that are passed down the delivery chain may be more or less imperative, the policy enactments may still retain elements of the welfarist/ democratic discourse as absent presences. One example is the coach-relationships that were formed that built on qualities in the teacher-student relationship beyond the subject matter (Frelin \& Grannäs, accepted).

A shift has taken place in which schools move from compensation to competition. This entails a change of emphasis from the best of the student to the best of the school, objectives that are sometimes in tension - a tension that teachers are left to contend with. Teachers grappling with the intention to serve the best interests of the students and the best interests of the school at the same time often encounter a personal cost, such as working against one's professional judgement and the resulting intensification and overload of work, especially as these are absent presences within a managerial discourse aiming at standardization and efficiency. The practices of promoting student well-being and democratic influence are viewed by teachers as ends in themselves and as preconditions for student attainment. At the management level, these practices are viewed as hindering the very same attainment. This is an example of how practices at school level become absent presences at the management level.

\section{Conclusions}

Absent presences are phenomena that are pushed away and exist outside the new managerial discourse, whereas those that can and are allowed to occur become present presences (Frelin \& Grannäs, 2011). In this article we have shown how the notion of absent and present presences achieves several things: it first of all acknowledges the presence and significance of important but neglected processes in educational settings, and secondly highlights the practices by which they are marginalized. It also shows how counter-hegemonic moves, such as strengthening the role of the Student Council, can evoke counter-discourses, such as the welfarist/democratic one.

Finally, let us return to the question of the race to the top by asking who is at the top? The irony of the measures taken to overcome the 'fact' that 'we (countries) are all left behind' is that they backfire when they contribute to 
an increased regime of accountability and an audit culture. However, the phenomena that we consider to be produced as absent presences - involving the fundamentally important public democratic deliberation of the purposes of education - prevent schools from ending up with more people being left behind, rather than fewer.

\section{References}

Apple, M. W. (1999). The absent presence of race in educational reform. Race, Ethnicity \& Education, 2(1), 9.

Apple, M. W. (2004). Controlling the work of teachers. In D. J. Flinders \& S. J. Thornton (Eds.), The curriculum studies reader (pp. 183-197). New York: N.Y.: Routledge Falmer.

Apple, M. W. (2007). Ideological success, educational failure?: On the politics of No Child Left Behind. Journal of Teacher Education, 58(2), 108-116.

Apple, M. W. (2009). Some ideas on interrupting the right: On doing critical educational work in conservative times. Education, Citizenship and Social Justice, 4(87), 87-101.

Apple, M. W. (2010). The measure of success: Education, markets, and an audit culture. In T. Monahan \& R. D. Torres (Eds.), Schools under surveillance - Cultures of control in public education (pp. 175-193). Rutgers University Press.

Ball, S. J. (2004). Education for sale! The commodification of everything? Annual Education Lecture, Department of Education and Professional Studies, King's College London, University of London. Retrieved September 16, 2013 from http:// firgoa.usc.es/drupal/node/25448.

Ball, S. J., Maguire, M., \& Braun, A. (2012). How schools do policy: Policy enactments in secondary schools. London \& New York: Routledge.

Ball, S. J., \& Olmedo, A. (2013). Care of the self, resistance and subjectivitiy under neoliberal governmentalities. Critical Studies in Education, 54(1), 85-96.

Barber, B. R. (2003). Strong democracy: Participatory politics for a new age (Twentieth-anniversary ed.). Berkeley, Calif.: University of California Press.

Beach, D., \& Sernhede, O. (2011). From learning to labour to learning for marginality: School segregation and marginalization in Swedish suburbs. British Journal of Sociology of Education, 32(2), 257 - 274.

Bejerot, E. (2013) Professioner i fokus. Fakta om professioners arbetsvillkor: Diagram om lärare. [Professions in focus. Facts on professions' work conditions. Diagrams on teachers.] Retreived September 16, 2013, from Stockholm University website: http:/ / www.pifokus.se/larare/diagram\#cT1HNTEmcD1BMiZvPTAsMSwyLDMsNA

Bieber, T. , \& Martens, K. (2011). The OECD PISA study as a soft power in education? European Journal of Education, 46(1), 101-116.

Bingham, C., \& Sidorkin, A. M. (2004). The pedagogy of relation: An introduction. In C. Bingham \& A. M. Sidorkin (Eds.), No education without relation. New York: P. Lang.

Blomqvist, P., \& Rothstein, B. (2008). Välfärdsstatens nya ansikte: demokrati och marknadsreformer inom den offentliga sektorn ([Ny utg.] ed.). Stockholm: Agora. 
Bottery, M., \& Barnett, R. (1996). The challenge to professionals from the New Public Management: Implications for the teaching. Oxford Review of Education, 22(2), 179. Boyatzis, R. E. (1998). Transforming qualitative information: thematic analysis and code development. London; Thousand Oaks, CA: SAGE.

Braun, V., \& Clarke, V. (2006). Using thematic analysis in psychology. Qualitative Research in Psychology, 3(2), 77-101.

Bunar, N. (2008). The free schools "riddle": Between traditional social democratic, neo-liberal and multicultural tenets. Scandinavian Journal of Educational Research, 52(4), 423-438.

Creswell, J. W. (2009). Research design: Qualitative, quantitative, and mixed methods approaches ( $3^{\text {rd }}$ ed.). Thousand Oaks, Calif: Sage.

Davidson, A. Locke. (1999). Negotiating social differences: Youths' assessments of educators' strategies. Urban Education, 34(3), 338-369.

Englund, T. (1994). Education as a citizenship right-a concept in transition: Sweden related to other Western democracies and political philosophy 1. Journal of Curriculum Studies, 26(4), 383-399.

Englund, T. (2010). Questioning the parental right to educational authority - arguments for a pluralist public education system. Education Inquiry, 1(3), 235-258.

Fransson, G., \& Grannäs, J. (2013). Dilemmatic spaces in teachers work - Towards a conceptual framework for dilemmas in teachers work. Teachers and Teaching: Theory and Practice, 19(1), 4-17.

Frelin, A. (2013). Exploring Teachers' Relational Professionalism in Schools. Rotterdam: Sense Publishers.

Frelin, A., \& Grannäs, J. (2011). Questioning the modern conception of time - The Politics of complexity reduction in education. Paper presented at the AERA, New Orleans. Frelin, A., \& Grannäs, J. (forthcoming). Navigating middle ground. A spatial perspective on the borderlands of teacher-student relationships in secondary school. In D. B. Zandvliet \& M. T. Mainhard (Eds.), Interpersonal relationships in education: From theory to practice Rotterdam: Sense Publishers.

Frelin, A., \& Grannäs, J. (accepted). Direct and indirect educational relationships: The varying significance of content in school relationships. Paper to be presented at the 2013 AARE conference, Adelaide, Australia.

Furlong, J., Cochran-Smith, M., \& Brennan, M. (2008). Editorial. Teachers and teaching: Theory and practice, 14(4), 265-269.

Gewirtz, S. (1997). Post-welfarism and the reconstruction of teachers' work in the UK. Journal of Education Policy, 12(4), 217-231.

Gewirtz, S., \& Ball, S. (2000) From 'welfarism' to 'new managerialism ': Shifting discourses of school headship in the education marketplace. Discourse: Studies in the Cultural Politics of Education, 21(3), 253-268.

Grannäs, J. (2011). Framtidens demokratiska medborgare: Om ungdomar, medborgarskap och demokratifostran i svensk skola. (Doktorsavhandling), Uppsala Universitet, Uppsala.

Hargreaves, A. (2000). Mixed emotions: teachers' perceptions of their interactions with students. Teaching and Teacher Education, 16(8), 811.

Hopmann, S. T. (2008). No child, no school, no state left behind: schooling in the age of accountability. Journal of Curriculum Studies, 40(4), 417-456. 
Hoyle, E., \& Wallace, M. (2007). Beyond metaphors of management: The case for metaphoric re-description in education. British Journal of Educational Studies, 55(4), 426-442.

Kaščák, O., \& Pupala, B. (2011). Governmentality - neoliberalism - education: The risk perspective. Journal of Pedagogy, 2(2), 145-160.

Kumashiro, K. K. (2008). The seduction of common sense: How the right has framed the debate on America's schools. New York Teachers College Press.

Laitsch, D. (2013). Smacked by the invisible hand: The wrong debate at the wrong time with the wrong people. Journal of Curriculum Studies, 45(1), 16-27.

Leys, C. (2003). Market-driven politics: Neoliberal democracy and the public interest. New York: Verso.

Lingard, B., Hayes, D., \& Mills, M. (2003). Teachers and productive pedagogies: Contextualising, conceptualising, utilising. Pedagogy, Culture \& Society, 11(3), 399-424. Lipman, P. (2009). Beyond accountability: Toward schools that create new people for a new way of life. In A. Darder, M. Baltodano \& R. Torres (Eds.), The critical pedagogy reader (pp. 364-383). New York, London: Routledge.

Lipman, P. (2010). Politics by other means - Education, accountability and the surveillance state. In T. Monahan \& R. D. Torres (Eds.), Schools under surveillance - Cultures of control in public education (pp. 159-174). New Brunswick, New Jersey, and London: Rutgers University Press.

Locke, R. R. (2009). Managerialism and the demise of the Big Three. Real-world Economics Review, 51(1), 28-47.

Minarechová, M. (2012). Negative impacts of high-stakes testing. Journal of Pedagogy, 3(1), 82-100.

Mulcahy, D. (2010). Assembling the 'accomplished' teacher: The performativity and politics of professional teaching standards. Educational Philosophy and Theory, 43 (1), 94-113.

Müller, J., Norrie, C., Hernández, F., Sancho, J. M., Creus, A., \& Larraín, V. (2011). European school teachers' work and life under restructuring: Professional experiences, knowledge and expertise in changing contexts. In I. F. Goodson \& S. Lindblad (Eds.), Professional knowledge and educational restructuring in Europe (pp. 65-80). Rotterdam: Sense Publishers.

NAfE. (2012). Betygsinflation - betygen och den faktiska kunskapsutvecklingen. [Grade inflation - grades and the actual knowledge development.] (Dnr 2012:387).

Oreshkina, M., \& Greenberg, K. (2011). Teacher-student relationships: The meaning of teachers' experience working with underachieving students. Journal of Pedagogy, $1(2), 52-66$.

Ranson, S. (2003). Public accountability in the age of neo-liberal governance. Journal of Education Policy, 18 (5), 459-480.

Skolverket. (2011). Curriculum for the compulsory school system, the pre-school class and the leisure-time centre 2011. Stockholm: Swedish National Agency for Education.

Skolverket. (2012). Likvärdig utbildning i svensk grundskola?: en kvantitativ analys av likvärdighet över tid. Stockholm: Skolverket.

Takayama, K. (2013). OECD, 'Key competencies' and the new challenges of educational inequality. Journal of Curriculum Studies, 45(1), 67-80. 
Taubman, P. M. (2009). Teaching by numbers : deconstructing the discourse of standards and accountability in education. New York: Routledge.

Wedin, A-S.. (2007). Lärares arbete och kunskapsbildning. Utmaningar och inviter $i$ den vardagliga praktiken [Teacher's work and knowledge creation. Challenges and contextual invitations in everyday practice]. Diss. Linköping: Institutionen för beteendevetenskap och lärande Linköpings universitet.

Wilkins, A. (2012). Pedagogy of the consumer: The politics of neo-liberal welfare reform. Journal of Pedagogy, 3(2), 161-173.

Yates, L. (2013). Revisiting curriculum, the numbers game and the inequality problem. Journal of Curriculum Studies, 45(1), 39-51.

Yin, R. K. (2003). Case study research: design and methods (3 ed.). Thousand Oaks: Sage Publications.

Zembylas, M. (2003). Emotions and Teacher Identity: A poststructural perspective. Teachers and Teaching, 9(3), 213-238.

\section{Author:}

Anneli Frelin, Ph.D.

University of Gävle

Faculty of Education and Business Studies

80176 Gävle

Sweden

email: anefrn@hig.se

Jan Grannäs, Ph.D.

University of Gävle

Faculty of Education and Business Studies

80176 Gävle

Sweden

email: jgs@hig.se 